\title{
WHAT KIND OF CASTLE?
}

\author{
Robert Pearce ${ }^{\star}$
}

\section{The castle defences}

\section{Introduction}

"The house of every one is to him as his castle and fortress, as well for his defence against injury and violence, as for his repose."

So resolved the judges of England in 1604. ${ }^{1}$

This is not just an ancient aphorism. It is one of the fundamental principles of the law of property which has been repeated and explained many times. Lord Denning has expressed the sentiment in colourful terms (adopting a quotation from the Earl of Chatham): ${ }^{2}$

\footnotetext{
"The poorest man may in his cottage bid defiance to all the forces of the Crown. It may be frail - its roof may shake - the wind may blow through it the storm may enter - but the King of England cannot enter - all his force dares not cross the threshold of the ruined tenement. So be it - unless he has justification by law."
}

But what kind of castle is it? For we all know that the fortress is under attack. It is under attack, not only by forces without, but also by forces within. I will give some examples later of how the castellan in his castle or the poor man in his cottage may repel the forces without. My main theme here, though, is the attack from forces within, a matter which despite its importance has received little attention from English writers.

The problem arises where residential accommodation is shared. What kind of castle is it if the sharers cannot agree?

* Professor of the Law of Property and Equity, University of Buckingham. An inaugural lecture delivered at the University of Buckingham in July 1992.

1. Semayne's case (1604) 5 Co.Rep. 91a, at 91b; 77 E.R. 194, at p. 195.

2. Southam v. Smout [1964] I Q.B. 308, at p. 320. 
Three classes of issue arise with which I shall deal in turn. The first is how secure the rights of occupation of the sharers are. Can one evict the other? On the one hand, what kind of castle is it if you can be turned out? On the other hand, what kind of castle is it if, though you may be secure in your occupation, you are obliged to sleep with the enemy?

The second class of issue is how difficulties between sharers can be resolved while they remain together. Who is king of the castle if the castle is shared? What kind of castle is it if you are not master in your own home?

Finally, what rights have sharers to admit others to the property? What kind of castle is it if you cannot close the castle doors?

Even in a stable housing market these are real and live issues. They have become more important because of the cycle of boom and bust in the residential property market. The explosive rise in house prices in the decade to 1989 and the subsequent equally explosive drop in prices has left a fallout. It has always been the case that married (and unmarried) couples have set up home together. But in the late 1980s this went further. Many people unrelated by marriage or physical and emotional attraction were obliged to share either to set foot upon the road to the purchase of their own home or to find accommodation at all. That in itself may have given rise to problems where those sharing the property failed to agree, but in many cases it was possible to escape through the expedient of sale. Now that route of escape has been curtailed. The subsequent collapse of the residential property market has meant that many house purchasers are trapped by their mortgages, having taken out mortgages representing a high fraction of the purchase price of their homes when prices were booming. Now they find the value of the house has fallen below the sums outstanding on the mortgage, or that they would be left with an insufficient deposit to finance another purchase. Over one million households may be affected. They cannot clear their debt by sale, and they cannot afford to move. However difficult it is to share, they are locked in. ${ }^{3}$

\section{Repelling the forces without}

Let me start with some illustrations which show how seriously the law treats invasions of a man's home. The starting point is that, in the absence of some lawful authority justifying the entry of the intruder, the owner of land is entitled to absolute control over his land. ${ }^{4}$ This can mean, for instance, that he can prevent a

3. A similar problem arises for those sharing secure rented accommodation, although the problem is here at its greatest at a time of housing shortage. Even in times of housing surplus there may be disincentives for the sharers to give up their accommodation, for instance where the property has been let at below market rent.

4. See Entick v. Carrington 19 St. Tr. 1029, at p. 1066 where Lord Camden LCJ said: "By the laws of England, every invasion of private property, be it ever so minute, is a trespass. No man can set his foot upon my ground without my licence, but he is liable to an action, though the damage be nothing ... If he admits the fact, he is bound to show by way of justification, that some positive law has empowered or excused him." 
neighbour from using a tower crane which occasionally swings into his airspace, ${ }^{5}$ or stop a neighbour erecting scaffolding on his land to carry out repairs, even if the consequence of this lack of co-operation is that the neighbour will have to demolish his building. ${ }^{6}$ It will not be until early in 1993, when the Access to Neighbouring Land Act 1992 comes into operation, that as a last resort where neighbours cannot agree it will be possible to obtain an access order from the High Court or County Courts. ${ }^{7}$

The landowner's rights to control the use of his land extend to refusing access to visitors, even those who may have important matters to see to. The classic illustration is Davis v. Lisle. ${ }^{8}$ Two policemen walked through the open door of a garage to make enquiries of the occupier. In doing this, the police were not trespassing since leaving the door of business premises open constitutes (in the words of the judge, Mr. Justice Goddard)" "an invitation to all persons having business with the owners of the premises to go to the premises and to enter the premises." The garage proprietor, however, asked the police to leave, and when they made no move to do so, he assisted their egress. One of the policemen's tunics was torn as a result. The court held that the garage proprietor was entitled to use reasonable force to remove the policemen.

A visitor who is asked to leave must, however, be given a sufficient period of grace to quit the premises. In Robson v. Hallett ${ }^{10}$ a police sergeant was invited into a house by the householder's son and was almost immediately asked to leave by the father. Before he was able to do so, the father assaulted him. The question arose whether the sergeant was a trespasser at the time of the assault. It was held that he was not. Lord Justice Diplock said that after the sergeant's invitation to come into the house had been withdrawn, ${ }^{11}$

5. Woollerton $\mathcal{E}$ Wilson v. Richard Costain Ltd. [1970] 1 All E.R. 483.

6. Fohn Trenberth v. National Westminster Bank Ltd. (1979) 39 P. \& C.R. 104.

7. There has long been legislation applying to London giving neighbours limited rights of entry for the purpose of carrying out repairs: London Building Acts (Amendment) Act 1939.

8. [1936] 2 K.B. 434. For a recent similar case, see Plenty v. Dillon (1991) 98 A.L.R. 353. Two police officers were attempting to serve a summons on Mr. Plenty concerning an offence which Mr. Plenty's 14 year old daughter was alleged to have committed, requiring her to appear before a juvenile court. Mr. Plenty, in communications with the police, had made it quite clear that any service should be made by post and that the police would not be welcome on his land. Nevertheless, although it was not disputed that they had no permission from Mr. Plenty, the police came to his farm with the summons. They did not have a welcoming reception. They found $\mathrm{Mr}$. Plenty in his garage and attempted to serve the summons by leaving it on the seat of his car. There was a struggle in which Mr. Plenty attempted to strike one of the police officers with a piece of wood. They arrested him, and he was subsequently convicted of assaulting the officer in the execution of his duty. For some reason $\mathrm{Mr}$. Plenty does not appear to have challenged that conviction, but he did bring an action against the police for damages for trespass. He succeeded in this action in the High Court of Australia. The Court held that the police had no common law or statutory right to enter Mr. Plenty's land against his express wishes for the purpose of serving a summons; that he was entitled to resist their entry, and that he was entitled to damages to vindicate his right to the exclusive use and occupation of his land.

9. At p. 440.

10. [1967] 2 Q.B. 939.

11. [1967] 2 Q.B. 939 , at p. 954. 
"the sergeant had a reasonable time to leave the premises by the most appropriate route for doing so, namely, out of the front door, down the steps and out of the gate, and provided that he did so with reasonable expedition, he would not be a trespasser while he was so doing."

By using force to eject the policeman before he had a chance to leave on his own, the householder was guilty of assaulting the officer while acting in the execution of his duty.

The owner or occupier of premises, then, has the right to pull up the drawbridge, lower the portcullis and exclude all unwanted visitors from his property.

There are some exceptions. A landowner does not have control over the airspace above his property to an unlimited height. ${ }^{12}$ And some uninvited visitors can pass the castle walls even against the wishes of the castellan. At common law a policeman or citizen could enter without consent to prevent a murder taking place, or to arrest a fugitive who had committed a serious criminal offence (that is a felony) and who had been followed to the premises. There are also a number of statutory provisions which permit entry to premises without the consent of the occupier. We have already come across one in the Access to Neighbouring Land Act 1992. Another statutory provision is that a policeman with a warrant has the right to enter, by force if necessary, although only after first knocking to request that the doors be opened. ${ }^{13}$ Utility companies have certain statutory rights to enter premises uninvited, ${ }^{14}$ and so too does the Exciseman: the Officer of Her Majesty's Customs and Excise investigating an enterprise dealing in alcoholic liquor or other dutiable goods. ${ }^{15}$ The Anton Piller order, ${ }^{16}$ under which the courts permit access to property for the purpose of collecting evidence for a civil case, also represents a serious inroad into the exclusivity of the rights of the landowner. ${ }^{17}$

\section{Lord Bernstein of Leigh v. Skyviews and General Ltd. [1978] Q.B. 479.}

13. Police and Criminal Evidence Act 1984, ss. 8-16.

14. See, e.g., Water Industry Act 1991, ss. $168-172$; Electricity Act 1989, s. 24 and Sched. 6 paras. 5-8; Rights of Entry (Gas and Electricity Boards) Act 1954, s. 2 as amended by Electricity Act 1989, s. 112. 15. Customs and Excise Management Act 1979, ss. 112, 113. S. 118C (added by the Finance Act 1991, s. 12) contains wider and more general powers.

16. Anton Piller K.G. v. Manufacturing Processes Ltd. [1976] Ch. 55.

17. What makes this inroad into the rights of the landowner remarkable is that it has been introduced by the judges who in other contexts have emphasised the exclusivity of the landowner's rights. See, for instance, Morris v. Beardmore [1980] 2 All E.R. 753 where the House of Lords affirmed the sanctity of the home in holding that the police could not enter a man's home without permission in order to demand a specimen of breath. The decision was followed in Lambert v. Roberts [1981] 2 All E.R. 15, at p. 19 where it was held that a policeman who had followed a driver onto a private driveway and there sought a breath test had no right to demand the test since his permission to be on the driveway could be, and had been, terminated without prior notice. In two later cases where the police similarly demanded a breath test from a driver parked on his own driveway, however, the Queen's Bench Divisional Court affirmed the decisions of the magistrates that telling the policemen to " $\mathrm{f}$... off' was insufficient to determine the implied licence which a householder extends to visitors to walk up his driveway if they have business with him: Gilham v. Breidenbach [1982] R.T.R. 328n.; Snook v. Mannion [1982] R.T.R. 


\section{Expelling the enemy}

The greatest threat to the privacy and repose of the householder, however, comes from those with whom he (or she) shares the property. Most householders do not occupy their house on their own. They share with spouse and family, or friend, or relative.

\section{The sole owner and the invited guest}

One situation in which an owner of a house shares with another is fairly easily dealt with. As cases like Davis v. Lisle show, the fact that an owner has invited or allowed someone onto his land does not prevent the owner from asking the visitor to leave, provided only that the visitor is given a reasonable time within which to make his exit. This is true both of the casual visitor, and also someone who has been invited to the property, for instance for dinner, or to stay for the weekend. It is true even if the relationship is of longer duration still, such as the son who looks after his elderly mother in his own home. The length of the invitation, or the duration of the stay which has already taken place will be relevant. Someone who has been a guest for a year is entitled to rather more time to pack her bags than the dinner guest. Apart from this, unless there is some additional factor, giving special protection, something which we shall look at in a moment, the owner is entitled at any time to ask his guest to go.

\section{The effect of a contract}

One of the factors which may prevent or restrict a householder in removing a guest is the existence of a contract. The guest (or licensee as such a guest is generally called) may have paid for the privilege to share the property, like a hotel guest, or a spectator at a cinema. ${ }^{18}$

The existence of a contract almost certainly means that the owner can be prevented arbitrarily and without justification from removing the licensee ${ }^{19}$ except in accordance with the terms of the contract. That may not, however, greatly inhibit the ability of the householder to remove the licensee, since the contract may allow the owner to ask the licensee to leave at short notice. The judicial assumption is

321. In the latter of these two cases Forbes J emphasised that there was a signiticant distinction between entering the driver's dwellinghouse and approaching him on a driveway. See also D.P.P. v. Gaffney [1988] I.L.R.M. 39.

18. There were occasions in the past when the courts were prepared to imply a contract, even where there had been no express agreement (see Tanner v. Tanner [1975] 3 All E.R. 776; Hardwick v. fohnson [1978] 2 All E.R. 935; Chandler v. Kerley [1978] 2 All E.R. 942) but this is a rather artificial exercise which has not in recent years been fashionable, and a contract is now likely to be found only where there has been some express agreement (see Horrocks v. Forray [1976] 1 All E.R. 737 and the discussion in Dawson and Pearce, Licences Relating to the Occupation or Use of Land (1979), pp. 25-28).

19. This would appear to be the effect of Hurst v. Picture Theatres Ltd. [1915] I K.B. 1 and Verrall v. Great Yarmouth Borough Council [1981] Q.B. 202. Wood v. Leadbitter (1845) 13 M. \& W. 838 which suggests the contrary is a decision prior to the Judicature Acts and so takes no account of the availability of an injunction to prevent a removal which is in breach of contract. 
that contractual rights to share the use of land are not intended to be of perpetual duration, and if the parties themselves have reached no agreement about when the contractual rights can be terminated, they can be terminated on reasonable notice. ${ }^{20}$

\section{The effect of estoppel}

Another way in which the owner of a house may be limited in his ability to evict an unwanted guest is by reason of what is called estoppel. If the owner of the house has led a visitor to believe that the visitor will be allowed to remain in the house free from the threat of eviction, and the visitor has acted in reliance upon that belief in such a way that she would be prejudiced should the owner evict her, then the owner will not be allowed to renege on the reasonable expectation which he has induced. ${ }^{21}$

This principle of estoppel (i.e., stopping the landowner from enforcing his unfettered legal rights) can protect rights to share accommodation, as in Greasley v. Cooke..$^{22} \mathrm{~A}$ woman entered the family home as housekeeper to the father, and later cohabited with one of his sons for over 30 years. The Court of Appeal held that, on the son's death, she could stay on in the house for as long as she wished. The family had led her to believe that she would be allowed to do so, and she had acted on that belief by looking after members of the family, including a mentally handicapped daughter, without receiving or seeking payment.

In most cases, once an equity has arisen in favour of a claimant by virtue of a change of position in reliance upon a legitimate and reasonable expectation

20. Australian Blue Metal Ltd. v. Hughes [1963] A.C. 74; Winter Garden Theatre (London) Ltd. v. Millennium Productions Ltd. [1948] A.C. 173; Minister of Health v. Bellotti [1944] K.B. 298: see Dawson and Pearce, pp. 84-90.

The very limited protection which a contract may give is illustrated by Frieze v. Unger [1969] V.R. 230. Jacob Frieze was a retired tailor who had a half-interest in a three-bedroomed maisonette. Being a bachelor and, it seems, rather infirm, he wished to live with a family who would be prepared to artend to his wants. He therefore came to an arrangement in writing with the Ungers, a family who responded to his advertisement in the Australian Jewish Herald, that they would move into the house with him, meeting all the gas and electricity bills, paying $£ 110$ s per week, and providing Jacob with all his meals and doing his laundry. The court held that although the arrangement was one under which the Ungers were paying what might be described as a rent, and for five years had the free run of the majority of the flat, it was clear from the arrangement that Jacob was intended to remain master and owner in his own house and home. The Ungers were simply lodgers without any statutory protection. Their right to remain on the property was a precarious one which could be brought to an end at any time consistently with the terms of the agreement with Jacob Frieze. They could be required to leave after the seven-day notice provided for in their written agreement.

21. The classic illustration of this is Inwards v. Baker [1965] 2 Q.B. 29. A son wanted to build a bungalow, but could not afford to buy a site. The father suggested that the son build on the father's land. The son did so. The Court of Appeal held that the son should be allowed to remain there "as long as he desires to as his home". In the words of Lord Denning, MR: "In this case it is quite plain that the father allowed an expectation to be created in the son's mind that this bungalow was to be his home. It was to be his home for life, or at all events, his home as long as he wished it to remain his home." The prejudice the son would have suffered had he been turned out is apparent, for he would have lost the money and effort he put into the building.

22. [1980] 3 All E.R. 710. 
induced or encouraged by the landowner, the measure of the entitlement of the claimant will be the fulfilment of that expectation. Sometimes, however, the landowner may be able to satisfy the requirements of equity by making good any prejudice which would be suffered in some other way, such as providing alternative accommodation. In Dodsworth v. Dodswort $h^{23}$ the owner of a house allowed her brother and his wife to move in with her. Believing that they would be allowed to remain, they made improvements costing a substantial sum. The Court held that they would be entitled to remain until they had been compensated for their labour and this capital expenditure. ${ }^{24}$

\section{A stake in the property}

The effect of an estoppel may be to give the claimant a right to share the property until compensated for any prejudice which an eviction would cause; a right to the use of the property for a limited period; or even an indefinite and irrevocable right to use the property. The estoppel can go even further, and confer on the claimant a proprietary share in the property. That is what I need to look at next.

With the great spread of owner-occupation and the increasing number of two income households, it is increasingly rare for adults sharing property not all to have a claim in the property. That stake can arise in two principal ways. It might, first, be formally recognised by the couple - as will usually be the case - having the property transferred into both their names. ${ }^{25}$

Secondly, even if the couple do not expressly recognise that both have a stake in the property, the circumstances of the acquisition of the property may be such that, even though it has been put into the name of one of them only, he (as is usually the case) will be compelled by the courts to treat the property as if it had been acquired in the names of both. Although on the face of things he is solely entitled to the property, he will hold it upon constructive trust for both.

When a constructive trust will be imposed upon a sole owner in this sort of situation is now at least reasonably well settled by a recent decision of the House of Lords, Lloyds Bank Ltd. v. Rosset. ${ }^{26} \mathrm{Mr}$. and Mrs. Rosset acquired and renovated a dilapidated farmhouse. Virtually all the money for the purchase and improvements came from Mr. Rosset's family trust, which insisted that the property be conveyed into the name of Mr. Rosset alone. Mrs. Rosset's contribution was not financial, but consisted, by and large, of the supervision of building work.

The House of Lords indicated that there are two ways in which it is possible for someone like Mrs. Rosset to assert a claim to a share in the property. The first is where there had been a common intention, evidenced by some express agreement or discussion between the parties, that the non-owner would acquire a share in the

23. (1973) 228 Estates Gazette 1115.

24. It is by no means clear how a right of this kind should be characterised. See Re Sharpe (A Bankrupt) [1980] 1 W.L.R. 219. See also Hussey v. Palmer [1972] 1 W.L.R. 1286.

25. For present purposes it does not matter whether this is as joint tenants or as tenants in common. 26. [1991] l A.C. 107. 
property. If, on the faith of that understanding, the non-owner spent money to help with the acquisition of the property, or in making improvements, in some significant way, then the owner would not be permitted to go back on the common understanding. ${ }^{27}$

The second way in which a share in a property can be acquired is that even without any express common intention, direct contributions to the acquisition of the family home by the person without legal ownership may have been made on such a scale that no one could possibly have made such a contribution unless they expected to receive a share in the property. If the acts concerned, and therefore the inferred expectation, were known to the legal owner, then he would be obliged to fulfil that expectation. ${ }^{28}$

In the Rosset case itself, the court found no evidence of any common intention to share ownership of the property, and indeed the insistence of the family trust that the house should be conveyed into Mr. Rosset's name alone was an indication to the contrary. The contribution Mrs. Rosset made to the renovations was also not of such a scale as to lead to the inference that she should obtain a stake in the house. She was not doing any more than most wives would do in seeking to make a house into a home, and her financial contributions were negligible. ${ }^{29}$

As can be seen from the articulation I have given of the principles set out by the House of Lords in Lloyds Bank Ltd v. Rosset, there is no marked difference in this context between the principles of constructive trust and the principles of equitable estoppel. The two concepts are referred to in the opinion of the Lords as if they are interchangeable. I believe that in this instance equitable estoppel and constructive trust are two closely related manifestations of the broader principle that legitimate expectations will be protected.

I embarked on the brief consideration of whether the sharers of property have proprietary interests because it is extremely relevant to whether the owner of the property can seek to turn a sharer out. The proprietary interest of the sharer gives her a right to occupation. She cannot be turned out against her will. ${ }^{30}$ If the man

\section{Eves v. Eves [1975] 3 All E.R. 768 and Grant v. Edwards [1986] Ch. 638 are examples.}

28 . In the first kind of case, the common intention might well be that the couple concerned would share the property equally, in return for acquiring the property by their joint efforts. Ownership would then be divided equally between them, notwithstanding that their contributions may not have been of equal value. In the second kind of case, because there is no expressed division of ownership, the court infers an intention to share ownership in proportion to the value of the contributions made to the acquisition. 29. The courts in Canada have been prepared to go further. They have taken the view that even without a common intention, a cohabitee can claim a share in the property where the legal owner has been enriched at the expense of the claimant, and there was no juristic reason for this enrichment. Applying these criteria, providing housekeeping services or domestic work could merit conferring a proprietary interest. See Rabichuck v. Cartwright (1990) 26 R.F.L. (3d) 206 where for contributions similar to those of Mrs. Rosset a social worker who supervised the internal decorations was held entitled to $\$ 200,000$ from the proceeds of sale of a $\$ 600,000$ home. And in Kutt v. Sam (1990) 26 F.L.R. (3d) 268 a similar amount was acquired by a woman whose contribution had been through childrearing.

30. Bull v. Bull [1955] 1 Q.B. 234; Tubman v. Fohnston [1981] 12 N.I.J.B. For a discussion of the effect of the trust on rights of occupation, see infra. 
says: "I'm the King of the Castle; you're the dirty old rascal", the woman can respond in similar vein. Neither of the two co-tenants, whatever their respective shares, can claim to be entitled to the property without the other. Both are entitled to possession of the whole property, and this joint or common right continues until the property is sold. For either to exclude the other from the property is an actionable wrong which sounds in damages and can be restrained in an appropriate case by injunction. The only situation in which it is likely that the court would enable one joint owner to exclude the other would be where the person it was sought to exclude had so conducted himself by violence or other gross behaviour that he made it impossible in practice for the other co-tenants to exercise their rights. ${ }^{31}$

Where the co-tenants cannot reach agreement about the termination of their relationship, the only practical solution in most cases is for an application to be made for the property to be sold by order of the court. ${ }^{32}$ Even this possibility is not available if the property is held on a periodic tenancy with no residual value. ${ }^{33}$ Where a sale is possible, the court has a discretion whether to order a sale, and the principles on which that discretion will be exercised are now fairly well settled. They are not, however, central to my theme.

\section{The owner and his spouse}

Quite apart from the nature of the interest (if any) which a sharer may have in the house she occupies, some sharers have a right to protection based on status. A householder who is married, or has children, may well find that the lordship he has of his castle is seriously compromised by the rights of the members of his family. I mention only this: under the statutory powers of the courts in matrimonial cases ${ }^{34}$ the castellan who invites his wife to join him in the castle may find not only that he may be prevented from evicting her, but even that she may obtain a court order requiring him to leave so that she can remain. ${ }^{35}$ What kind of castle is that?

\section{Living with the Enemy}

The rules relating to the termination of rights of occupation have received a good deal of attention over the years and present no especial difficulty. A matter which

31. See Lord Diplock in Davis v. Fohnson [1979] A.C. 264, at p. 330.

32. Under s. 30, Law of Property Act 1925.

33. The court is effectively without any power to decide which rights of occupation should prevail: Ainsbury v. Millington [1986] 1 All E.R. 73; Waugh v. Waugh (1982) 3 F.L.R. 375.

34. Matrimonial Homes Act 1983. The same fate may even befall the unmarried proprietor. The Domestic Violence and Matrimonial Proceedings Act 1976 permits the county court to make exclusion orders to deal with domestic violence in the case of both married couples and also of unmarried couples where a man and a woman are living together in the same household as husband and wife. Although it was initially thought that this provision did not enable the court to override common law property rights, the House of Lords decided in Davis v. Fohnson [1979] A.C. 264 that the Act applied regardless of whether the person excluded was sole or joint owner of the home.

35. Her rights of occupation cease on divorce absolute, although the court has power to make orders relating to the occupation of property in ancillary proceedings. 
provides rather greater difficulty is the regulation of rights of occupation between those sharing accommodation. How can those sharing the occupation of property resolve their disputes as to the use of the property if they cannot reach agreement?

\section{The gratuitous guest}

The answer to that question depends upon the nature of the arrangement under which they share. In some cases that relationship makes one the seigneur whose rights will prevail. If the host does not wish his dinner guest to smoke, he is perfectly entitled to ask the guest who insists on lighting up to leave. ${ }^{36}$ And as we have seen, it is no different if the guest has been invited for the weekend or longer: the nature of a gratuitous permission is that it can be withdrawn at any time, merely upon giving the guest or licensee a reasonable time within which to leave. ${ }^{37}$ It follows that the host can insist as a condition of allowing the guest to remain that the guest conforms to the behaviour which the host demands.

\section{The contractual licensee}

Where the position of the subordinate occupier is more secure, then the rights of the owner are less draconian. Where there is a contract, then the licensee is entitled to remain in occupation for the duration of his contractual rights. The owner cannot therefore change the rules as he goes along. The question must instead be whether the licensee has stepped outside the rules of conduct permitted by the contract. If he has not, he cannot lawfully be removed so long as his contractual right to remain subsists. Of course, if he does step outside the terms of his invitation, he loses his right to stay. ${ }^{38}$ The interpretation of the contract will ultimately be a matter for the court.

\section{The licensee by estoppel}

Where a sharer's occupation is protected by estoppel, the matter of regulation is wholly unclear. As in the case of occupation protected by contract, it is not open to the owner of the property to impose his rules of conduct under the threat of the termination of the rights of occupation. Obviously, however, there must be some limits on the conduct which either user of the property can inflict upon the other. Some guidance may be had from an unreported Irish decision. A farmer had left his farm to one of his sons, but had given his other children personal but irrevocable rights of residence.

The farming son and the others ran into problems. The children were in the habit of travelling down from Dublin at weekends. They were rather relaxed about the care they took in parking, so that the farming brother found that not infrequently he could not get his tractor out of the farmyard. The family was

\section{Robson v. Hallett [1967] 2 Q.B. 939.}

37. Coombes v. Smith [1986] I W.L.R. 808.

38. This was implicit in Hurst v. Picture Theatres Ltd. [1915] 1 K.B. 1. A cinema spectator who was misbehaving would not be entitled to the protection of Equity. 
unable to resolve the problem itself, and the matter ended up in the courts. The decision of the judge was that he did have power to regulate the relationship, but he was not prepared to exclude the rights of any of the children. He directed that the rights of the farming brother should prevail. He was the owner of the farm. The other children had only a right to use it. He would not prevent them from making their weekend visits, but when they did so, they were to park in such a way as not to impede access to the farmyard. ${ }^{39}$

\section{Co-tenants}

Like the position of the occupier protected by estoppel, the position of co-tenants in dispute between themselves is something which has received little attention. That there is a jurisdiction on the part of the courts to intervene I do not doubt, yet my researches have failed to identify any English decisions directly in point. It may well be that the law cannot hope to resolve all the difficulties which can arise between co-tenants, and that they are often better left to resolve matters between themselves. But that is also the case in regard to neighbours, and yet the law does not hesitate there to offer remedies. Should not the same kinds of remedy be available to those who share? As between neighbours, each is required to use his property reasonably, so as not to interfere with the like right of the other. I can thus be restrained by injunction if I make noises late at night which disturb the peace of my neighbour, or if I pollute my neighbour's property with smells or smoke. In each case my conduct is considered by law to constitute an actionable nuisance. Is there something so special about the tort of nuisance that it should not also be available between those who share? ${ }^{40}$ Perhaps Lord Justice Ormrod shared my view. In Waugh v. Waugh ${ }^{41}$ he said:

"There is no doubt, I imagine, that one joint tenant can obtain an injunction restraining various acts or conduct on the part of the other joint tenant who makes life impossible."

Quite apart from this kind of nuisance, there can be other problems concerning the use of shared property which are susceptible to regulation, like the parking in the Irish rights of residence case. It is frequently said that co-tenants each have a right to the use of the entire property. Neither may exclude the other from any part of it. Yet that opinion goes too far. As was said in one American case:42

"Co-tenants cannot actually occupy in common every part of the premises, no matter what their description. If they live together in the mansion house,

39. This is an unreported first instance decision of about 1985-1989. Since first reading it $I$ have been unable to trace the transcript, and the account of the case is based on memory.

40. Co-tenants, just like neighbours, have proprietary rights which can support the action.

41. (1982) 3 F.L.R. 375, at p. 377.

42. Mastbaum v. Mastbaum 9 A 2 d 51 (1939), at p. 55. 
still each has exclusive possession of his own bedroom. If the property be a farm, unless they are willing to go into partnership, one must till certain fields and one other fields. Two men cannot plow the same furrow."

If a mother and her son share the mansion house they are each likely to want the privacy of their own rooms. If they cannot agree, can there not be an application to court as a last resort? Similarly if a father leaves his holiday home to his children but they cannot agree on how to take turns to use it, could a court not resolve their difference?

The nearest illustration I have been able to find of this kind of application concerned a rocking chair which passed to the two children of the deceased owner. ${ }^{43}$ Neither wanted a sale because the sentimental value of the chair far exceeded its commercial value. The court could, I suppose, have adopted the judgment of Solomon and required the chair to be cut in two. Instead the judge ordered the executrix of the deceased's estate not to sell the chair and ordered that the two children should be permitted to take the chair for six month turns until they voluntarily terminated the arrangement.

\section{The Fifth Column}

There is very little authority on the extent to which a person sharing the occupation of a property may invite others to it. As in the other two areas at which we have already looked, the position depends on the form of shared occupation. At the one extreme the sole legal and beneficial owner of property has the fullest liberty to invite others to the property. At the other extreme a person with no legal or equitable right in a property, and who is not even in occupation of that property, has no right to permit others to enter it.

\section{Occupiers without title}

What is the position if a person living at a house by permission of the owner, but with no better right than that invites another to the property? It may be that should make no difference. There is a principle in law (though subject to many exceptions), expressed in Latin as nemo dat quod non habet, that no one can give a better right than they have themselves. ${ }^{44}$ No one would expect that an invitation to

\section{Re Estate of Burr C. McDowell, decd. 345 NYS 2d 828 (1973).}

44. An American case, People v. Weaver 241 Mich. 616, 217 NW 797, 58 A.L.R. 733 (1928), decided during the Prohibition, illustrates this. The husband had been placed on probation for a violation of the prohibition law. As one of the conditions he had signed a document permitting the authorities to search without warrant any business or domestic premises which were occupied by him during the term of his probation. Mrs. Weaver had commenced divorce proceedings against her husband, and was buying her own house, but Mr. Weaver lived in her house when he was not away from home on work. Relying on the husband's letter of authority, the police searched the wife's home where they found some home-brewed beer in the fridge. Mrs. Weaver was charged and convicted of unlawful possession. The Michigan Supreme Court overturned the conviction, finding that there was an inconsistency: if the husband's consent could be relied upon to justify the search, then it should have followed that the home 
spend the weekend as a country house guest would include the right to bring a friend - unless that had been expressly stated in the invitation. But if the relationship is of rather longer duration, such as where a man and woman are cohabiting, our reaction might be rather different. If I am living in a stable relationship with a friend in a property which belongs entirely to my friend, is a colleague I invite to join me for a drink before Sunday lunch inevitably a trespasser unless I have specifically obtained clearance? I think our answer here would be that I can invite my colleague to join me, however futile my invitation may be in that if my own permission to be on the property can be terminated without prior notice, my colleague can equally peremptorily be asked to leave. ${ }^{45}$

So how can the two situations that I have just outlined be reconciled? The answer lies, $\mathrm{I}$ believe, in what the contract lawyers call implied terms. ${ }^{46}$ When we enter into bargains we do not always specify in detail how all the issues that might arise during our relationship are to be resolved. The law makes good some of these omissions. Sometimes the law will import an implied obligation because that is necessary to give reasonable efficacy to the bargain. In other cases, the law may presume agreement (in the absence of anything said to the contrary) if the point is such that, had an officious bystander interjected and said "You have forgotten to deal with this", the parties would have said "But, of course, we took that for granted."

These approaches provide our answer. If I am invited for the weekend, my invitation permits me to bring my luggage: I will need that to change for dinner. It is reasonably necessary to the enterprise, quite apart from being within the test of what is taken for granted. But bringing an extra guest of my own goes beyond the scope of the invitation on either test.

Where my invitation is of longer duration, the response is rather different. ${ }^{47}$ Unless I am staying in a hermitage, or the contrary has otherwise been made clear, my permission to reside with my friend will extend to rendering the ordinary civilities of life and ordinary acts of social intercourse. That would be taken for granted, and is a reasonably necessary incident of residing in a house. Inviting a

was his as a matter of law. If Mrs. Weaver was to be treated as the head of the household for the purpose of the criminal charge, then she was entitled to the Constitutional protection which an American citizen has against the use of evidence obtained in an unlawful search.

45. A different view is expressed in Dawson and Pearce, Licences Relating to the Occupation or Use of Land, p. 132 where greater emphasis is placed on the absence of any right (in the sense of title) on the part of the gratuitous bare licensee, and it is suggested that "Because the bare licensee himself has no right he cannot, in virtue of what he does not have (i.e., a right), authorise, as an incident thereto, a third party to enjoy part of the benefit of it." That view fails to take account of the possibility that a gratuitous licence may imply as an incident the liberty to invite others to the property.

46. See Dawson and Pearce, pp. 141-142.

47. Romer LJ in Frank Warr \& Co. Ltd. v. London County Council [1904] 1 K.B. 713, at pp. 722-3 suggested that in construing a licence a distinction was to be drawn between licences for pleasure which should be strictly construed - and licences for profit - which could more readily be construed as extending to the servants of the licensee. It is submitted that the distinction between profit and pleasure is only one of the factors to which regard should be had in construing the licence. 
colleague to share a drink would be permissible; but inviting him to move in long-term without the special permission of the householder would not.

What is reasonable clearly requires a balancing of the interests of both sharers. As was said in one American case: ${ }^{48}$

"Joint occupancy of property, particularly residential property, obviously demands reasonable restrictions on the right of each joint occupant either by himself or through another to exercise full control over the property at all times regardless of the wishes of another joint occupant present on the premises. A joint occupant's right of privacy in his home is not completely at the mercy of another with whom he shares legal possession."

In that case Nieman had been caught in possession of a substantial quantity of marijuana. He gave the police the keys to a flat in which he lived. As the police were trying to find the right key, the door was opened by Tompkins, who also lived there. On seeing the police, he slammed the door in their face. The police broke down the door and inside found marijuana seeds in a jar. Tompkins was charged and convicted of possession. By a majority of five to one, the Supreme Court of California in Bank held that Nieman's consent was not in the circumstances sufficient. The search was unlawful and the evidence obtained inadmissible.

\footnotetext{
"We hold that one joint occupant who is away from the premises may not authorize police officers to enter and search the premises over the objection of another joint occupant who is present at the time, at least where as in this case, no prior warning is given, no emergency exists, and the officer fails even to disclose his purpose to the occupant who is present or to inform him that he has the consent of the absent occupant to enter."
}

Furthermore, the court was of the opinion that Nieman's consent to a search could not have extended to such an arbitrary exercise of his right to possession as the breaking down of the door.

\section{Co-owners}

So far, in looking at the right of a house-sharer to invite guests I have considered only the position of a sharer with no title to the property. But, as we have already seen, more often than not nowadays sharers of residential property (other than children) can all claim to have a proprietary interest in the property which they share. Here there is the most difficult problem of all, and once again, the rules are by no means clear.

The starting-point for a consideration of the rights of co-tenants is Doe on the 
demise of Aslin v. Summersett. ${ }^{49}$ The Court of King's Bench concluded that where three of four joint landlords had given notice to quit under a periodic tenancy, the tenancy automatically came to an end. The court indicated that the tenant could remain in possession of the land as tenant of the share of the fourth landlord, sharing occupation with the other (former) landlords, but this required a new arrangement with that joint tenant. Summersett's case was referred to with approval by the Law Lords in the recent decision in Hammersmith $\mathcal{F}$ Fulham London Borough Council v. Monk. ${ }^{50}$ It was explained as an illustration of the principle that for decisions affecting the whole of a property held by co-tenants, all the co-tenants must agree. Each new period for which a periodic tenancy continues must, it was said, be treated as a tacit renewal, and so required the concurrence of all. The House of Lords did not comment on the ability of one co-tenant to lease his own share, but the remarks in Summersett's case on this point reflect the orthodox view that a co-owner is able to create derivative rights to the land concerned out of his own interest. Although this point may not be easy to follow, it is something which, for the sake of my thesis, I must emphasise.

Take the case of a husband and wife. Together they acquire a property. But then they fall out. Can the husband rent his share in the house - or even sell it - to a stranger? Lord Denning thought that possibility so repugnant that in Bedson v. Bedson ${ }^{51}$ he said that where a husband and wife had acquired a property as joint tenants, it was not possible for either to alienate their interest to a stranger. Russell LJ in the same case thought that proposition to be without any foundation in law or in equity, ${ }^{52}$ and subsequent comments on the point have affirmed the Russell rather than the Denning view. ${ }^{53}$ The Russell view is also supported by a whole battery of United States and Commonwealth cases. Space permits just one illustration, Cantazariti v. Whitehouse, ${ }^{54}$ a case heard on appeal by the Federal Court of Australia. Mr. and Mrs. Cantazariti were joint owners of what was the matrimonial home until the marriage broke up and Mrs. Cantazariti moved out. Mr. Cantazariti subsequently let the house to Mr. Whitehouse who did not know of the wife's interest in the property and thought that he was obtaining vacant possession of the whole property. Mr. Cantazariti told his wife that he was using the rent to meet the mortgage payments on the house. When she discovered that he was not, Mrs. Cantazariti asked Mr. Whitehouse and his family to leave. They did not, so she entered the house by breaking a window and climbing in. She proceeded to throw clothing, linen and crockery belonging to Mr. Whitehouse into the backyard; Mr. Whitehouse's dogs got in through the broken window and

49. (1830) 1 B. \& Ad. 135.

50. (1991) 63 P. \& C.R. 373.

51. [1965] 2 Q.B. 666 .

52. [1965] 2 Q.B. 666 , at p. 690.

53. Re Draper's Conveyance [1969] I Ch 486; Cowcher v. Cowcher [1972] 1 W.L.R. 425; Harris v. Goddard [1983] 1 W.L.R. 1203; Fleming v. Hargreaves [1976] 1 N.Z.L.R. 123.

54. [1981] 55 F.L.R. 426. 
caused further damage. Following this, initially against the opposition of $\mathrm{Mr}$. Whitehouse, but later with his agreement, she moved back into one of the rooms of the house. Mr. Whitehouse brought an action claiming to be entitled to the occupation of the house, and also claiming compensation for the damage to his belongings. Part of the dispute became otiose since before the hearing, Mr. Whitehouse left the house.

The Full Court, in a written judgment, stated that the grant of the lease by Mr. Cantazariti was effective to bind his own share, but not that of his wife. She was, however, obliged to recognise the right of occupancy her husband had conferred on Mr. Whitehouse. ${ }^{55}$

"The agreement between the appellant's husband and the respondent
entitled the respondent to use and occupy the whole of the premises together
with the appellant. She retained her right as joint tenant equally to use and
enjoy the whole estate. But she was not entitled to attempt to prevent the
respondent from exercising his right of use and occupation. In particular she
was not entitled to damage his goods and chattels. Her conduct in this latter
regard constituted an actionable infringement of the respondent's rights."

This, I emphasise, represents the orthodox position. It is against that background that we have to look at some of the recent English decisions. Those decisions, however much in accordance with our feelings of propriety, are difficult to defend on their application of law.

There are four cases at which I wish to look. Three are from the Court of Appeal. The other is a decision of a County Court judge. I will start with that case since the decision has little standing in the heirarchy of judicial authority. It is Sanders v. $M c$ Donald. ${ }^{56} \mathrm{Mr}$. Pringle and Mrs. Sanders, an unmarried couple, were joint tenants of a council flat where they lived with Mrs. Sanders' adult daughter. After the couple's relationship broke down, Mr. Pringle brought Miss McDonald, his new girlfriend, to live with him. Mrs. Sanders moved to another bedroom. One imagines that the relationship was rather strained: the two families kept their bedrooms padlocked and lived separately. After about a year of this arrangement Mrs. Sanders sought to terminate any licence which Miss McDonald had to occupy the flat. Since Mr. Pringle did not agree to terminate the licence, he was joined as a defendant.

The County Court judge, Judge Harris, ordered Miss McDonald to go. He held that:

"one joint tenant cannot grant any interest, including a licence, in the land without the agreement, express or implied, of the other joint tenant. Mrs. 
Sanders did not agree to Miss McDonald's presence and actively objected to it and, accordingly, Miss McDonald never had any interest in the flat as licensee; if [that finding] was wrong, the notice in July 1979, although given by one joint tenant only and against the wishes of the other joint tenant, determined any interest Miss McDonald might have had." 57

This is not an isolated case for, as I have said, there are also decisions of the Court of Appeal to consider. The first of these was Robson-Paul v. Farrugia. ${ }^{58}$ The plot here is rather complicated. Mr. Farrugia, one of the defendants, clearly had a fondness for women, and was none too honest. Although he was already married, he went through a bigamous ceremony of marriage with the unsuspecting plaintiff, Miss Robson-Paul. The two of them bought a house together in their married names, on the face of it as joint tenants. At some stage Miss Robson-Paul moved out and Mr. Farrugia brought another woman to live with him in the house. The next step in the saga was that there was an attempt to sell the house to Miss Dimitriou, Miss Robson-Paul's signature being forged by a woman claiming to be her (probably the woman with whom Mr. Farrugia was then living). When Miss Robson-Paul found out about the sale, she had the transfer declared void, and in the present proceedings she sought to recover possession of the property from Miss Dimitriou, who had moved in and refused to leave. Miss Dimitriou had not pleaded that the forged transfer, although ineffective to transfer ownership of the whole house, was at least effective to transfer to her the share of Mr. Farrugia. An attempt to introduce that claim at a late stage was rejected for technical reasons. ${ }^{59}$ Instead, Miss Dimitriou argued that Mr. Farrugia had given her a licence to occupy the premises, and that licence could not be terminated by Miss Robson-Paul.

Lord Justice Davies doubted whether it could truly be said that a licence could be implied from the fraudulent transfer.$^{60}$

\footnotetext{
"Assuming, however, that such a licence is to be implied from Farrugia's transaction, it seems to me to be quite impossible to say that such a licence cannot be terminated by the other joint tenant or tenant in common without the agreement of both. If one can grant a licence - as to which, quaere -, surely, the other can revoke the licence. Otherwise, the licence would remain in the premises ad infinitum."
}

57. Citing Doe d. Aslin v. Summersett (1830) 1 B. \& Ad. 135.

58. (1969) 20 P. \& C.R. 820.

59. See at p. 823. Had it not been for the failure to plead or argue this matter in the County Court, Miss Dimitriou should have had a strong case: see First National Securities Ltd. v. Hegerty [1985] Q.B. 850 where a mortgage instrument bearing the signature of one joint tenant and the forged signature of his wife, the other joint tenant, was held to be effective to create an equitable mortgage over the share of the husband alone, although ineffective in regard to the share of the wife.

60. (1969) 20 P. \& C.R. 820 , at p. 825. 
Lord Justice Megaw accepted that a licence was purported to be given, but he said that it purported to be a licence to take possession of the entire property. It was not suggested, he said, that there was any principle of law that one co-owner had implied authority to grant a licence of the whole of the property without the consent of the other co-owner. Mr. Farrugia's attempt to grant a licence of the whole house was an attempt to do something which he had no authority to do. As such it could not be effective "for any purpose against any person who would be affected thereby." 61

Plowman J, the third judge in the court, said simply that he agreed and that he could not usefully add anything.

What the judges in the case appear to assume is that the licence, if there is any given, must and can only be a licence of the entire property. This overlooks the possibility that an attempt by one co-owner to give possession of the whole house, although inoperative for that purpose, since it requires authority from both co-owners, could be at least operative to grant rights against the grantor alone. $\mathrm{Mr}$. Farrugia surely did not need authority from anyone to confer rights of occupation out of his own interest in the property. And if $\mathrm{Mr}$. Farrugia could grant rights arising from his own interest alone, then, as counsel for Miss Dimitriou argued, why should Miss Robson-Paul be any better able to obtain possession from her than she could from Mr. Farrugia?62

This case, although before the Court of Appeal, was argued in just one day. The extemporary judgments were given the same day, and only one case in point was cited. Just as we can dispense with Sanders v. McDonald as being of little persuasive authority, so also we might regard this decision as concerned with a very unusual situation, poorly thought through, and decided without proper regard to previous decisions. But it cannot be rejected so easily. The decision has been followed and applied in a subsequent Court of Appeal decision, Annen v. Rattee ${ }^{63}$ In this case two Canadian drama students, Miss Annen and Mr. Wagar, bought a flat in London, intending it to be their future matrimonial home. Only Mr. Wagar moved in. He shared the use of the flat with a series of drama students. One of these fellow students was the defendant Paul Rattee. He stayed on in the flat after Mr. Wagar returned to Canada in 1979. When Miss Annen learnt of this,

61. (1969) 20 P. \& C.R. 820 , at p. 828.

62. Megaw LJ indicated that counsel for Miss Dimitriou had referred to the decision in Bull v. Bull [1955] 1 Q.B. 234 that one co-owner could not evict another and had put the question forensically: "Should that principle not apply equally to prevent a tenant in common from getting an order for possession against someone to whom his fellow tenant in common has transmitted possession?" Megaw LJ furnished his response. "I think that the answer to that question might well be 'No'. Indeed, I think that it might well be put the other way round: why should someone to whom the possession of the whole property has been transmitted by the tenant in common have protection against the obtaining of an order for possession by the other tenant in common who has not concurred in that transfer of possession?" It is evident from this response that Megaw LJ was again not considering the possibility of the grant of a licence by Mr. Farrugia operating out of his own interest alone.

63. (1985) 273 E.G. 503; [1985] E.G.D. 136. 
she objected and made efforts to get him out. After some delay, she sent a letter purporting to terminate his licence. Mr. Wagar did not know of this, nor, it follows, did Mr. Wagar consent to Miss Annen's actions. Mr. Rattee still did not leave. He claimed that the licence to live in the flat given to him by Mr. Wagar could not be terminated by Miss Annen.

The Court of Appeal affirmed the decision of the County Court judge that this licence had validly been determined. Stephenson LJ began his opinion on this matter with a discussion of Doe d. Aslin v. Summersett ${ }^{64}$ and subsequent cases dealing with the termination of leases granted by joint tenants. Those did not, of course, include the recent decision of the House of Lords in Hammersmith and Fulham L.B.C. v. Monk. ${ }^{65}$ Lord Justice Stephenson came to the view that Summersett's case, as subsequently interpreted, had decided that a notice to quit given by one co-owner was effective to determine a tenancy. He could find no point of distinction between that case and the issue which he had to decide. Miss Annen was therefore able to terminate the licence given by Mr. Wagar. In reaching this conclusion, Lord Justice Stephenson entirely overlooked the possibility of the grant of rights operating against the interest of one co-tenant alone. He was therefore mistaken about the effect of a purported termination by the other co-tenant. He said that he was fortified in coming to that conclusion by the Court of Appeal decision in the Robson-Paul case, but of course that decision suffers from just the same fault. After setting out the decision in that case, he said:

"The resemblance of that case to this is limited, but nevertheless striking. It
seems to me that what Lord Justice Davies said, 'If one can grant a
licence . . then ... the other can revoke the licence. Otherwise, the
licensee would remain in the premises ad infinitum', applies just as much to a
case of a sharing occupation as it does to an occupation, whether under
licence or tenancy, of the whole of a property."

Lord Justice Lloyd, the other judge in this two-judge court, gave a concurring opinion. He also, without adverting to the possibility of one co-owner granting rights operating against his own interest only, said that Summersett's case and subsequent cases, including Robson-Paul v. Farrugia, bound them to the view that notice by any one co-owner was effective to determine a licence to occupy the property.

As I hope I have already demonstrated, these two Court of Appeal decisions, far from representing the orthodox view, are heretical and unsound. But there is still a third Court of Appeal decision to consider. This one is the strangest of them all. It 
is Chhokar v. Chhokar. ${ }^{66}$ The Chhokars' marriage had some ups and downs. They had bought a house together in 1977 as their family home, both contributing to the purchase, so that Mrs. Chhokar had a stake in it, although it was transferred into the name of Mr. Chhokar alone. In $1978 \mathrm{Mr}$. Chhokar attempted to abandon his pregnant wife in India, leaving her destitute. He failed. Mr. Chhokar then, without the knowledge of his wife, sold the family home to a Mr. Parmar for a price about $30 \%$ below open market value. Completion took place while the wife was in hospital to have her baby. Mr. Chhokar collected the net proceeds of sale in cash, and disappeared with them to India. The wife did not see him again for two years. When she came out of hospital on 22 February, she went home to find that Mr. Parmar had moved in and changed the locks. She had to spend the night with an aunt. The next day Mrs. Chhokar managed to get into the house, but she was thrown out by Mr. Parmar. She managed to get back into the house again in early March. Two days later Mr. Parmar arrived with a few men he called builders, broke into the house, and smashed the lavatory and every window in the house. Mrs. Chhokar was assaulted and badly bruised, and there was a threat to throw her baby out of the window. After this, it seems that Mrs. Chhokar was left in the house without further molestation. In $1981 \mathrm{Mr}$. Chhokar returned to England. Although his relationship with his wife was rather strained, he did occasionally stay at the house, and by the time the case came to trial the judge was sure that there would be a full resumption of cohabitation.

The court was faced with a variety of claims, some of which are fortunately not relevant to our present discussion. The Court of Appeal agreed that the effect of the sale to Mr. Parmar was that he had acquired the same right to the property as the husband had prior to the sale: that is, he had acquired legal ownership, but that in equity he was beneficial tenant in common with the wife. The court, however, refused to order a sale, because this would have deprived the innocent wife of her rights of occupation. The court was quite happy to contemplate Mr. Chhokar joining her at the house, even though he had parted with all proprietary interest in the house to Mr. Parmar. But what of Mr. Parmar. Could he move into the house? What the court said was this:

\footnotetext{
"Mr. Brock [the barrister representing Mr. Parmar] submits that he has a right in law to occupy the property, but he goes on in the next breath to concede that it is a right that cannot be exercised because he succeeded to the rights of the husband in the matrimonial home. Mr. Parmar is a married man himself and no court would allow him to try to occupy the matrimonial home in common with Mrs. Chhokar (and for all I know Mrs. Parmar might have something to say about it too, if he tried to do so)."
}

It is this point, put so casually that the judge feels able to make a poor joke, and as if 
the matter were uncontroversial and free from doubt, which raises the very greatest difficulty. Why is it that a man who has bought a half-share in a house is told that he cannot live there?

That he is a married man is entirely beside the point. If Mrs. Chhokar can live there with her husband, why should not Mr. Parmar be able to live there with his wife? It cannot, I think, be argued that Mr. Parmar had no right of occupation. Having a beneficial interest as tenant in common is generally understood to confer a right of occupancy, ${ }^{67}$ a view which has been affirmed in a series of cases including decisions of the House of Lords. These cases ${ }^{68}$ hold that a beneficial co-tenant, even where there is a trust, enjoys, by reason of that interest, a present right of occupation. Had it not been for that right of occupation, indeed, Mrs. Chhokar would not have had any claim to remain in the house after her husband had sold it: she would instead have had to rely on a claim against him for a share in the price he received.

It seems, therefore, that the acquisition of a beneficial interest by Mr. Parmar should have been enough to confer on him a right of occupation. If the court was denying the existence of any such right, it was wrong. The court could have asserted a jurisdiction to exclude Mr. Parmar from the premises on the basis that his earlier conduct had been so reprehensible that Mrs. Chhokar could not be expected to live under the same roof as him; that only by excluding him could her own right of occupation be preserved. But, as we have already seen, the courts have denied any general jurisdiction to terminate rights of occupation as between co-owners, ${ }^{69}$ and this was not a situation where any statutory provisions applied. ${ }^{70}$

I do not shed tears for Mr. Parmar. It would not be easy to contemplate a person who had done more to merit the forfeit of his rights of occupation. But whether the courts in such a situation as this have the power to forfeit the rights of occupation of a beneficial co-owner was too disputatious to dismiss in one line and a joke.

67. There is an argument to the contrary. Since 1925, in all cases of co-ownership of a legal estate in land, with some possible but insignificant exceptions, the co-ownership takes effect by the imposition of a trust under which up to four trustees hold the legal interest in the property for the benefit of the co-owners, be they tenants in common or joint tenants. It has been argued that since the legal right in the property is held by the trustees, they are the persons who are legally entitled to possession, and if the beneficial co-tenants are allowed to occupy the property, it is only by permission of the trustees (see $R e$ Landi (Deceased) [1939] Ch. 828; Crane, (1955) 19 Conv. (n.s.) 146; Saunders and McGregor, (1973) 37 Conv. (n.s.) 270, at pp. 272-3). That argument has decisively been rejected. In any event, it would not have helped the Court of Appeal in this case, since the effect of the registration of the transfer following the sale to Mr. Parmar was to make him the trustee with the legal right to possession.

68. Bull v. Bull [1955] I Q.B. 234; Williams and Glyn's Bank v. Boland [1981] A.C. 487; City of London Building Society v. Flegg [1988] A.C. 54; Hammersmith and Fulham L. B.C. v. Monk (1991)63 P. \& C.R. 373.

69. See Ainsbury v. Millington [1986] 1 All E.R. 73.

70. Matrimonial Homes Act 1983; Domestic Violence and Matrimonial Proceedings Act 1976; Domestic Proceedings and Magistrates' Courts Act 1978. 


\section{Conclusion}

So we have completed our initial survey of the Englishman's castle. Much more remains to be explored, not just of the law, but also of the social and economic issues. What is my verdict on what we have found?

The relationship of most sharers of residential property is not often of the arms-length kind. While the relationship prospers, most differences can amicably be settled. When it does not, the problems can be severe. There are undoubtedly many situations in which the law can offer no direct help: no amount of legislation can restore to harmony a discordant personal relationship. Recourse to law is often also the very last resort: should it prove necessary to go to law the relationship may already have strained beyond breaking point. But still, in every negotiation over rights the law provides the backdrop. Friction may be reduced and out of court settlement of disputes eased where that backdrop is settled, practical, and well understood. That, I regret to say, is far from the case for those sharing residential property.

There are, then, criteria against which I believe that this branch of the law should be measured. It is of prime importance that the law should be clear. It is also important that reasonable settlement of disputes should be encouraged and arbitrary action restrained. In sum, a balance has to be drawn between the free exercise of rights of property and the protection of the reasonable expectations of those sharing its use.

I have examined three principal areas: first, the ability of the owner of property to evict his fellow-occupants; second, the regulation of the affairs of sharers of residential property while they remain together; and third, the rights of occupiers to permit others the use of the property.

How well do the three areas at which I have looked measure up to the criteria I have described? The first comes the closest to meeting them. The law concerning the termination of sharing is in flux, but I believe that it is moving in a way which satisfies my criteria. In the second, there is further to go before the criteria are satisfied. The law on the regulation of rights of sharers has yet to be developed, but it is within the means of the common law to develop it as I have suggested. In the third area, the balance has yet to be found when it comes to admitting strangers to the home: indeed the English courts have yet even to put the conflicting considerations properly on the scales.

With such uncertainty in the law, I think that it is with justification that I pose the question in my title: "What kind of castle?" 